\title{
Effects of abomasal lipid infusion on liver triglyceride accumulation and adipose lipolysis during fatty liver induction in dairy cows
}

\author{
A. E. Brickner, J. A. A. Pires, ${ }^{1}$ T. F. Gressley, ${ }^{2}$ and R. R. Grummer ${ }^{3}$ \\ Department of Dairy Science, University of Wisconsin, Madison 53706
}

\begin{abstract}
The objective was to determine the effects of abomasal infusion of linseed oil on liver triglyceride (TG) accumulation and adipose tissue lipolysis during an experimental protocol for induction of fatty liver. Eight nonpregnant, nonlactating Holstein cows were randomly assigned to treatments in a replicated $4 \times 4$ Latin square design. Treatments were abomasal infusion of water $(\mathrm{W})$, tallow $(\mathrm{T})$, linseed oil (LO), or half linseed oil and half tallow (LOT) at a rate of $0.56 \mathrm{~g} / \mathrm{kg}$ of body weight per day. Each experimental period consisted of a 4-d fast concurrent with administration of treatments into the abomasum in 6 equal doses per day (every 4 h). Cows were fed ad libitum for $24 \mathrm{~d}$ between periods of fasting and lipid infusion. Infusion of linseed oil (LO and LOT) increased $\alpha$-linolenic acid (C18:3n-3) content in serum $(12.2,10.4,4.2$, and $4.6 \mathrm{~g} / 100 \mathrm{~g}$ of fatty acids for LO, LOT, T, and $\mathrm{W}$, respectively), but not in the nonesterified fatty acid (NEFA) fraction of plasma. Treatments had no effect on plasma NEFA concentrations. Abomasal infusion of lipid increased in vitro stimulated lipolysis in subcutaneous adipose tissue, compared with W $(4,294,3,809,4,231$, and 3,293 nmol of glycerol released $\times \mathrm{g}^{-1}$ tissue $\times 2 \mathrm{~h}^{-1}$ for LO, LOT, $\mathrm{T}$, and $\mathrm{W}$, respectively), but there was no difference between fat sources. Hepatic TG accumulation over 4-d fast was $2.52,2.60,2.64$, and $2.09 \pm 0.75 \mu \mathrm{g}$ of $\mathrm{TG} / \mu \mathrm{g}$ of DNA for $\mathrm{W}$, LO, LOT, and T, respectively, which did not differ. Abomasal infusion of LO did not reduce liver TG accumulation, plasma NEFA concentration, or alter in vitro adipose tissue lipolysis when compared with $\mathrm{T}$. These results contrast with a previous study involving i.v. infusion of lipid emulsion derived from LO. Discrepancies might be explained by the use of different administration routes and a relatively mod-
\end{abstract}

\footnotetext{
Received February 19, 2009.

Accepted June 18, 2009.

${ }^{1}$ Current address: INRA, UR1213 Herbivores, Site de Theix, F-63122 Saint-Genès-Champanelle, France.

${ }^{2}$ Current address: Department of Animal and Food Sciences, University of Delaware, Newark 19716.

${ }^{3}$ Corresponding author: rgrummer@wisc.edu
}

est induction of liver TG accumulation in the current experiment.

Key words: linseed oil, liver triglyceride, bovine

\section{INTRODUCTION}

Fatty liver is a metabolic disorder typical of periparturient dairy cattle (Grummer, 1993). Plasma NEFA concentrations increase during periods of elevated fat mobilization from adipose tissue. Liver takes up NEFA proportionally to its concentration in blood and blood flow (Emery et al., 1992). Fatty acids can be fully oxidized, partially oxidized to ketones, or re-esterified to triglyceride (TG) in the hepatocytes. Compared with hepatocytes in rodents, ruminant hepatocytes are inefficient in exporting fatty acids as constituents of very low density lipoproteins (Kleppe et al., 1988) and appear unable to efficiently increase fatty acid oxidation and decrease esterification rates during negative energy balance caused by feed restriction (Lomax et al., 1983). Intensive mobilization of fat reserves leads to hepatic TG accumulation (Grummer, 1993), which may decrease gluconeogenesis (Cadorniga-Valino et al., 1997) and ureagenesis in the bovine (Strang et al., 1998), and predisposes cows to other metabolic disorders. For instance, experimentally induced ketosis is preceded by accumulation of TG in liver and depletion of glycogen (Veenhuizen et al., 1991).

Omega-3 (n-3) polyunsaturated fatty acids (PUFA) modulate energy metabolism in nonruminants by increasing lipid oxidation, decreasing lipid storage, and changing regulation of gluconeogenesis (Ikeda et al., 1998). Supplementation of rodent diets with fat sources rich in $\alpha$-linolenic acid (ALA) led to lower plasma and liver TG content, enhanced hepatic fatty acid oxidation rates, increased gene expression and activity of enzymes involved in fatty acid $\beta$-oxidation, and decreased gene expression and activity of hepatic lipogenic enzymes (Morise et al., 2006), compared with animals fed fat sources higher in saturated fatty acids. Polyunsaturated fatty acids can alter bovine hepatic metabolism in vitro (Mashek and Grummer, 2003). Additionally, i.v. infusion of an emulsion derived from linseed oil, which is a source rich in ALA, decreased accumula- 
tion of TG during fatty liver induction (Mashek et al., 2005). However, because plasma NEFA concentration was decreased by linseed oil, it was unknown whether the reduction of liver TG accumulation was due to direct effects on hepatocytes, indirect effects on adipose tissue metabolism, or both. Furthermore, it is unknown whether linseed oil delivered via intestinal absorption will produce the same effects on liver TG accumulation as i.v. administration. Therefore, the objectives were to determine whether linseed oil absorbed by the small intestine would lead to reduced liver TG accumulation during fatty liver induction, and to determine whether linseed oil modulates lipolysis in subcutaneous adipose tissue.

\section{MATERIALS AND METHODS}

All animal related procedures were approved by the University of Wisconsin College of Agriculture and Life Sciences Institutional Animal Care and Use Committee.

\section{Animals and Treatments}

Eight nonpregnant, nonlactating, rumen-cannulated Holstein cows weighing $723 \pm 61 \mathrm{~kg}$ with a BCS of $3.8 \pm$ 0.5 (mean $\pm \mathrm{SD}$ ) were randomly assigned to treatments in a replicated $4 \times 4$ Latin square design. Cows were fitted with an infusion tube into the abomasum (Gressley et al., 2006). Each period was $4 \mathrm{~d}$ of feed restriction to induce liver TG accumulation (Mashek et al. 2005). Treatments consisted of a $4 \mathrm{~d}$ abomasal infusion of water $(\mathbf{W})$, bovine tallow (T; HRR Enterprises, Chicago, IL), linseed oil (LO; Virtus Nutrition, Corcoran, CA), or a mixture of $50 \%$ tallow and $50 \%$ linseed oil (LOT), concomitant with feed restriction. All treatments were infused at a rate of $0.56 \mathrm{~g} / \mathrm{kg}$ of $\mathrm{BW}$ per day via the abomasal infusion line. Tallow was chosen as a second control to reflect the fatty acid profile found in ruminant adipose tissue while maintaining isocaloric intake across fat treatments. Treatments were administered every $4 \mathrm{~h}$ in 6 equal doses each day. Given this rate of infusion, a cow weighing $723 \mathrm{~kg}$ would receive $405 \mathrm{~g}$ of lipid or $\mathrm{W}$ daily. This rate would be equivalent to a cow eating $2 \%$ of its BW of a diet containing $2.8 \%$ TG (DM basis).

Two days before initiation of each period, cows were weighed to determine treatment dose; $1 \mathrm{~d}$ before initiation of infusions, cows were fitted with a jugular catheter to facilitate blood sampling. Catheters were filled with sterile saline containing heparin $(100 \mathrm{IU} / \mathrm{mL}$; Becton Dickinson, Franklin Lakes, NJ) to maintain patency between sampling times, and were removed at the end of each $4 \mathrm{~d}$ infusion period. Cows were given penicillin $\mathrm{G}$
(100 units/kg of BW per day i.m.; G. C. Hanford Mfg. Co., Syracuse, NY) as a prophylactic until $3 \mathrm{~d}$ after the end of each period. Rectal body temperature was taken every $4 \mathrm{~h}$ during infusion periods.

Cows were fed vitamins and minerals to meet maintenance requirements (NRC, 2001) during feed restriction, using wheat middlings as carrier (total of $0.5 \mathrm{~kg} / \mathrm{d}$ ). Cows were allowed ad libitum intake of a diet composed of alfalfa hay and haylage for $24 \mathrm{~d}$ between experimental periods to deplete hepatic TG accumulated during previous feed restriction. Animals had free access to water and a trace mineralized salt block throughout the trial. Cows were housed in tie-stalls and allowed access to an exercise lot for approximately $4 \mathrm{~h} / \mathrm{d}$ except during experimental periods.

\section{Blood and Tissue Sampling}

Approximately $20 \mathrm{~mL}$ of blood was sampled immediately before the initiation of each period and every $8 \mathrm{~h}$ thereafter. Because of an inoperative jugular catheter during period 1, one cow was sampled via coccygeal vein through all 4 periods. For harvesting plasma, 10 $\mathrm{mL}$ of blood was transferred to tubes (Becton Dickinson) containing sodium fluoride and potassium oxalate and immediately placed on ice. For collection of serum, $10 \mathrm{~mL}$ of blood was transferred to tubes containing clot activator and were kept at room temperature to allow clotting. Blood samples were centrifuged $(1,430 \times g$ for 15 min for plasma; $1,430 \times g$ for 30 min for serum) and aliquots were stored at $-20^{\circ} \mathrm{C}$ until analysis.

Liver biopsies were performed twice each period, $1 \mathrm{~d}$ before the initiation of feed restriction and again within $8 \mathrm{~h}$ after termination of infusions, following a procedure described previously (Vazquez-Anon et al., 1994). Liver samples were rinsed in saline, flash frozen in liquid $\mathrm{N}_{2}$, and stored at $-80^{\circ} \mathrm{C}$ for later analysis of TG and DNA. Adipose tissue was sampled from the tail head region (McNamara and Hillers, 1986) at the end of each period to assess in vitro lipolytic rates.

\section{Adipose Tissue Incubations}

Vascular tissue was separated and adipose tissue was sliced using a Stadie-Riggs hand microtome to yield approximately 150-mg explants. Explants were rinsed and incubated for $30 \mathrm{~min}$ in a Krebs-Ringer bicarbonate buffer containing $1.25 \mathrm{~m} M$ of calcium, $10 \mathrm{~m} M$ of HEPES, $5 \mathrm{~m} M$ of glucose, and $5 \mathrm{~m} M$ of acetate at $\mathrm{pH}$ 7.5 to remove lysed cells. Adipose explants were rinsed and incubated for $2 \mathrm{~h}$ at $37.5^{\circ} \mathrm{C}$ in the Krebs-Ringer bicarbonate buffer supplemented with 3\% BSA (A-3083, essentially fatty acid free, Sigma Aldrich Chemical Co., St. Louis, MO) to assess basal lipolysis, or including 
0.75 units $/ \mathrm{mL}$ of adenosine deaminase plus $0.01 \mathrm{~m} M$ isoproterenol bitartrate salt to study stimulated lipolysis rate (Vazquez-Anon, 1996). After 2 h, incubations were terminated by placing vials in ice for at least 10 min, and media was stored at $-20^{\circ} \mathrm{C}$ until analysis.

\section{Analyses}

Blood plasma was analyzed for NEFA (NEFA-C kit, Wako Fine Chemical Industries USA, Richmond, VA; Johnson and Peters, 1993). Adipose tissue incubation media were analyzed for NEFA (NEFA-C kit, Wako Fine Chemical Industries USA; Johnson and Peters, 1993) and glycerol (Free Glycerol Reagent, F-6428, Sigma Chemical Co.; McGowan et al., 1983). Liver samples were analyzed for TG and DNA as described by Mashek et al. (2005). Tallow and LO fatty acid composition was analyzed with a method adapted from Sukhija and Palmquist (1998) using nonadecanoic acid in chloroform $(2 \mathrm{mg} / \mathrm{mL})$ as the internal standard. Briefly, $2 \mathrm{~mL}$ of internal standard in chloroform and $3 \mathrm{~mL}$ of $5 \%$ methanolic $\mathrm{HCl}$ were added to $50 \mathrm{mg}$ of sample. Samples were vortexed and incubated for $2 \mathrm{~h}$ at $70^{\circ} \mathrm{C}$. After samples were cooled, $5 \mathrm{~mL}$ of $0.05 \mathrm{~N}$ $\mathrm{K}_{2} \mathrm{CO}_{3}$ and $2 \mathrm{~mL}$ of chloroform were added, samples were vortexed and centrifuged $(500 \times g$ for $10 \mathrm{~min})$, and the organic layer transferred and analyzed by gas chromatography using a Clarus 500 gas chromatograph (Perkin Elmer Autosystem, Norwalk, CT) equipped with a $100 \mathrm{~m} \times 0.25 \mathrm{~mm}$ i.d. wall-coated, open-tubular fused silica column coated with CP-Sil 88 (Chrompack \#CP7489, Varian Inc., Walnut Creek, CA). Initial oven temperature was $50^{\circ} \mathrm{C}$ (held for $0.4 \mathrm{~min}$ ), which was increased by $4^{\circ} \mathrm{C} / \mathrm{min}$ to a final temperature of $190^{\circ} \mathrm{C}$ (held for $110 \mathrm{~min}$ ). Temperatures of the injector and detector were $255^{\circ} \mathrm{C}$. Helium was used as the carrier gas at a linear velocity of $0.9 \mathrm{~mL} / \mathrm{min}$ with a split flow of $55 \mathrm{~mL} / \mathrm{min}$. Peaks were identified by commercially prepared external standards. These temperature gradient analyses were used to detect fatty acids from $\mathrm{C} 8$ to C22:6.

Blood serum lipids were extracted from samples collected at $96 \mathrm{~h}$ after the start of infusion, using 1.5 $\mathrm{mL}$ of serum and $15 \mathrm{~mL}$ of $2: 1$ chloroform to methanol mixture. The organic layer containing fatty acids from all lipid fractions was dried under $\mathrm{N}_{2}$, methylated, and analyzed as described previously. Plasma collected at 88 and $96 \mathrm{~h}$ of infusion was pooled for analysis of fatty acid profile of the NEFA fraction according to Mashek et al. (2005). Plasma (1.5 mL) was extracted in $15 \mathrm{~mL}$ of 2:1 chloroform: methanol; the organic layer was dried under $\mathrm{N}_{2}$ and resuspended in $100 \mu \mathrm{L}$ of chloroform. Extracted lipid was spotted on thin layer chromatog- raphy plates (Soft Layer Adsorbosil, \#16330, Alltech Assoc. Inc., Deerfield, IL), and developed in a chamber containing petroleum ether, diethyl ether, and glacial acetic acid (80:20:1). The NEFA layer was visualized with Rhodamine 6G (R-4127, Sigma Aldrich Chemical Co.), scraped into glass conical tubes and methylated with the previously described procedure without internal standard. The organic layer was transferred and analyzed by gas chromatography on a Clarus 500 gas chromatograph (Perkin Elmer Autosystem) equipped with a $1.8 \mathrm{~m} \times 2 \mathrm{~mm}$ i.d. column with GP $10 \%$ SP2330 on 100/120 Chromosorb WAW (Supelco Inc., Bellefonte, PA). Initial oven temperature was $75^{\circ} \mathrm{C}(4$ $\min$ ), which was increased $4^{\circ} \mathrm{C} / \mathrm{min}$ to a final temperature of $200^{\circ} \mathrm{C}$ (held for $14 \mathrm{~min}$ ). Temperatures of the injector and detector were $225^{\circ} \mathrm{C}$. Nitrogen was used as the carrier gas at a linear velocity of $1 \mathrm{~mL} / \mathrm{min}$.

\section{Statistical Analysis}

Data were analyzed as a $4 \times 4$ replicated Latin square design using the Mixed procedure of SAS (SAS Institute Inc., Cary, NC). The model included the fixed effects of period, treatment, and period by treatment interaction, the random effects of square and cow within square, and a residual error term. Plasma NEFA concentration was analyzed using repeated measures in time by including the fixed effects of time and time by treatment interaction in the model and using first order autoregressive covariance structure. Liver TG was analyzed as absolute value and as change in TG concentration during the 4-d fast. The model initially included prefasting TG concentration as covariate, but it was removed because significance was $P>0.25$. The period by treatment interaction was removed from the model to study liver TG accumulation because there were 4 missing observations ( 1 each for $\mathrm{T}$ and $\mathrm{LOT}$, and 2 for $\mathrm{W}$ ) due to difficulties in tissue collection or insufficient sample.

Predefined contrasts were used to test the effects of lipid infusion ( $\mathrm{W}$ vs. $\mathrm{LO}+\mathrm{LOT}+\mathrm{T})$, and linear ( $\mathrm{LO}$ vs. $\mathrm{T}$ ) and nonlinear (LOT vs. $\mathrm{LO}+\mathrm{T}$ ) effects of $\mathrm{LO}$ to determine if there was a dose effect of lipid source within isoenergetic treatments on plasma NEFA, adipose tissue lipolysis, and liver TG. Differences among treatment means for fatty acid composition of serum total lipids and NEFA fraction were determined using the PDIFF option of Mixed procedure of SAS (SAS Institute Inc.) when treatment effect was significant. Data from fatty acid analysis were log-transformed to correct for heterogeneity of variance; least squares means and standard error of the means were estimated from untransformed values, whereas $P$-values reflect 
Table 1. Fatty acid composition (g/100 g of fatty acids) of lipid sources for Holstein cows infused abomasally with water, linseed oil, linseed oil plus tallow, or tallow

\begin{tabular}{lcc}
\hline Fatty acid & Tallow & Linseed oil \\
\hline Myristic acid (C14:0) & 3.5 & 0.1 \\
Myristoleic acid (C14:1) & 1.1 & $\mathrm{ND}^{1}$ \\
Pentadecanoic acid (C15:0) & 0.4 & $\mathrm{ND}$ \\
Palmitic acid (C16:0) & 24.4 & 5.4 \\
Palmitoleic acid (C16:1) & 5.1 & 0.2 \\
Heptadecanoic acid (C17:0) & 1.2 & 0.1 \\
Stearic acid (C18:0) & 14.8 & 3.8 \\
Oleic acid (C18:1n-9) & 43.3 & 22.1 \\
Linoleic acid (C18:2n-6) & 2.5 & 16.8 \\
Alpha-linolenic acid (C18:3n-3) & 0.3 & 51.4 \\
Eicosenoic acid (C20:1) & 0.5 & $\mathrm{ND}$ \\
Docosanoic acid (C22:0) & 0.9 & 0.1 \\
Unknown & 2.0 & 0.1 \\
\hline
\end{tabular}

${ }^{1} \mathrm{ND}=$ not detected.

statistical analysis of transformed data. Significance was declared at $P<0.05$ and trends toward significance were declared at $P<0.10$.

\section{RESULTS AND DISCUSSION}

\section{Fatty Acid Composition}

Tallow and LO contained $89.0 \%$ and $89.1 \%$ fatty acids with the profile shown in Table 1 . The most common fatty acids in ruminant tissue $(\mathrm{C} 16: 0, \mathrm{C} 18: 0$, and C18:1) comprised $82.5 \%$ of the fatty acids in tallow, whereas C18:3 comprised 0.3\% (of which the majority was $\gamma$-linolenic acid; GLA). Linseed oil was $68.2 \%$ PUFA, and $51.4 \%$ of total fatty acids was C18:3. The fatty acid profile of $\mathrm{LO}$ and $\mathrm{T}$ was similar to fat sources used by Mashek et al. (2005).

Serum fatty acid composition is shown in Table 2 . Infusion of linseed oil (LO or LOT) increased the pro- portion of ALA (C18:3n-3) in serum $(P<0.05)$. Conversely, infusion of LO decreased total GLA (C18:3n-6) in serum. Previously reported values of GLA as a percentage of total fatty acids in blood ranged from undetectable in early lactation cows (Lessard et al., 2003 ) to just over 1\% in mid lactation cows (Lessard et al., 2003). It is not known what caused 3\% GLA as a percentage of total serum fatty acids during infusion of W.

There were no significant changes in proportion of ALA in the NEFA fraction (Table 3), possibly because of a dilution by endogenous fatty acids released from adipose tissue during feed restriction, or because of a rapid turnover of chylomicron-derived fatty acids in the blood. Nevertheless, Mashek et al. (2005) found a significant increase in ALA in the NEFA fraction following i.v. infusion of an emulsion derived from LO. In the current experiment, the plasma fractions with greatest content in ALA were phospholipid and cholesterol esters (data not shown). When long-chain PUFA were fed to dairy cattle, most appeared in the non-TG fraction of blood (AbuGhazaleh et al., 2003).

\section{Plasma NEFA Concentrations}

Plasma NEFA concentration increased from 226 to $903 \mu \mathrm{Eq} / \mathrm{L}$ during $96 \mathrm{~h}$ of feed restriction and infusions (Figure 1). There were no significant differences in plasma NEFA concentration among treatments. Mashek et al. (2005) noted a significant decrease in plasma NEFA when cows were feed-restricted and infused i.v. with an emulsion derived from linseed oil compared with tallow.

Intestinal absorption of $18 \mathrm{C}$ fatty acids increases with increased degree of unsaturation in nonruminants (Doreau and Chilliard, 1997). Estimates of intestinal

Table 2. Serum fatty acid composition (in $\mathrm{g} / 100 \mathrm{~g}$ of fatty acids) of Holstein cows infused abomasally with water (W), linseed oil (LO), linseed oil plus tallow (LOT), or tallow (T) at $0.56 \mathrm{~g} / \mathrm{kg}$ of BW per day during a 4 -d fast

\begin{tabular}{lrrrrr}
\hline & \multicolumn{5}{c}{ Infusion } \\
\cline { 2 - 4 } Fatty acid & \multicolumn{1}{c}{ W } & \multicolumn{1}{c}{ LO } & LOT & T & SE \\
\hline Palmitic acid (C16:0) & 16.17 & 13.87 & 15.12 & 17.25 & 1.34 \\
Palmitoleic acid (C16:1) & 0.85 & 0.75 & 0.75 & 0.18 & 0.47 \\
Heptadecanoic acid (C17:0) & 0.29 & 0.88 & 1.13 & 0.75 & 0.34 \\
Stearic acid (C18:0) & 14.78 & 13.88 & 15.63 & 14.25 & 1.48 \\
Oleic acid (C18:1n-9) & 15.92 & 18.38 & 15.13 & 17.88 & 2.13 \\
Linoleic acid (C18:2n-6) & 36.53 & 31.88 & 34.13 & 35.50 & 2.12 \\
Alpha-linolenic acid (C18:3n-3) & $4.55^{\mathrm{b}}$ & $12.25^{\mathrm{a}}$ & $10.38^{\mathrm{a}}$ & $4.25^{\mathrm{b}}$ & 0.65 \\
Gamma-linolenic acid (C18:3n-6) & $3.07^{\mathrm{a}}$ & $0.13^{\mathrm{b}}$ & $0.88^{\mathrm{ab}}$ & $1.38^{\mathrm{a}}$ & 0.66 \\
Eicosedienoic acid (C20:2) & 0.28 & 0.25 & 0.38 & 0.75 & 0.22 \\
Arachidonic acid (C20:4) & 6.54 & 4.50 & 5.35 & 5.00 & 0.74 \\
\hline
\end{tabular}

${ }^{\mathrm{a}, \mathrm{b}}$ Means within a row with no common superscript differ $(P<0.05)$.

${ }^{1}$ Data represent LSM with pooled SE. 
Table 3. Plasma NEFA composition (in $\mathrm{g} / 100 \mathrm{~g}$ of fatty acids) of Holstein cows abomasally infused with water (W), linseed oil (LO), linseed oil plus tallow (LOT), or tallow (T) at $0.56 \mathrm{~g} / \mathrm{kg}$ of $\mathrm{BW}$ per day during a 4 -d fast ${ }^{1}$

\begin{tabular}{lrrrrr}
\hline & \multicolumn{4}{c}{ Infusion } & \\
\cline { 2 - 4 } Fatty acid & \multicolumn{1}{c}{ W } & \multicolumn{1}{c}{ LO } & \multicolumn{1}{c}{ LOT } & \multicolumn{1}{c}{$\mathrm{T}$} & SE \\
\hline Palmitic acid (C16:0) & 22.64 & 16.97 & 21.00 & 19.80 & 2.77 \\
Palmitoleic acid (C16:1) & 1.04 & 0.98 & 2.45 & 1.68 & 0.64 \\
Stearic acid (C18:0) & 27.71 & 21.82 & 16.03 & 20.30 & 5.30 \\
Oleic acid (C18:1n-9) & 24.98 & 21.24 & 33.55 & 31.27 & 5.06 \\
Linoleic acid (C18:2n-6) & 4.75 & 23.23 & 9.73 & 15.69 & 7.55 \\
Alpha-linolenic acid (C18:3n-3) & 5.20 & 3.61 & 4.16 & 1.01 & 3.24 \\
Arachidonic acid (C20:4) & 0.77 & 2.86 & 0.84 & 1.11 & 1.15 \\
Other & 13.79 & 8.21 & 14.39 & 9.22 & 4.18 \\
\hline
\end{tabular}

${ }^{1}$ Data represent LSM with pooled SE.

absorption data for PUFA in ruminants are variable because of inaccuracy of flow markers and relatively small amounts of linoleic (C18:2) and linolenic (C18:3) escaping the rumen. Based on previous research in dairy cattle, there were no significant differences in digestion of $18 \mathrm{C}$ fatty acids when various sources rich in longchain fatty acids were infused abomasally (Bremmer et al., 1998). Nonetheless, ALA and oleic acid (C18:1) digestibility was 96.5 and $78.7 \%$, respectively, when canola oil was infused abomasally (Chelikani et al., 2004). The dairy cow has the ability to absorb over $1 \mathrm{~kg} / \mathrm{d}$ of lipid (Chilliard, 1993), but no more than $0.5 \mathrm{~kg}$ was infused each day in the current study. We expected minimal differences in the intestinal digestibility of fat sources because relatively modest amounts were infused every $4 \mathrm{~h}$ and cows were feed-restricted, which would lead to low digesta passage rates. Still, total serum fatty acids (those derived from NEFA, TG,

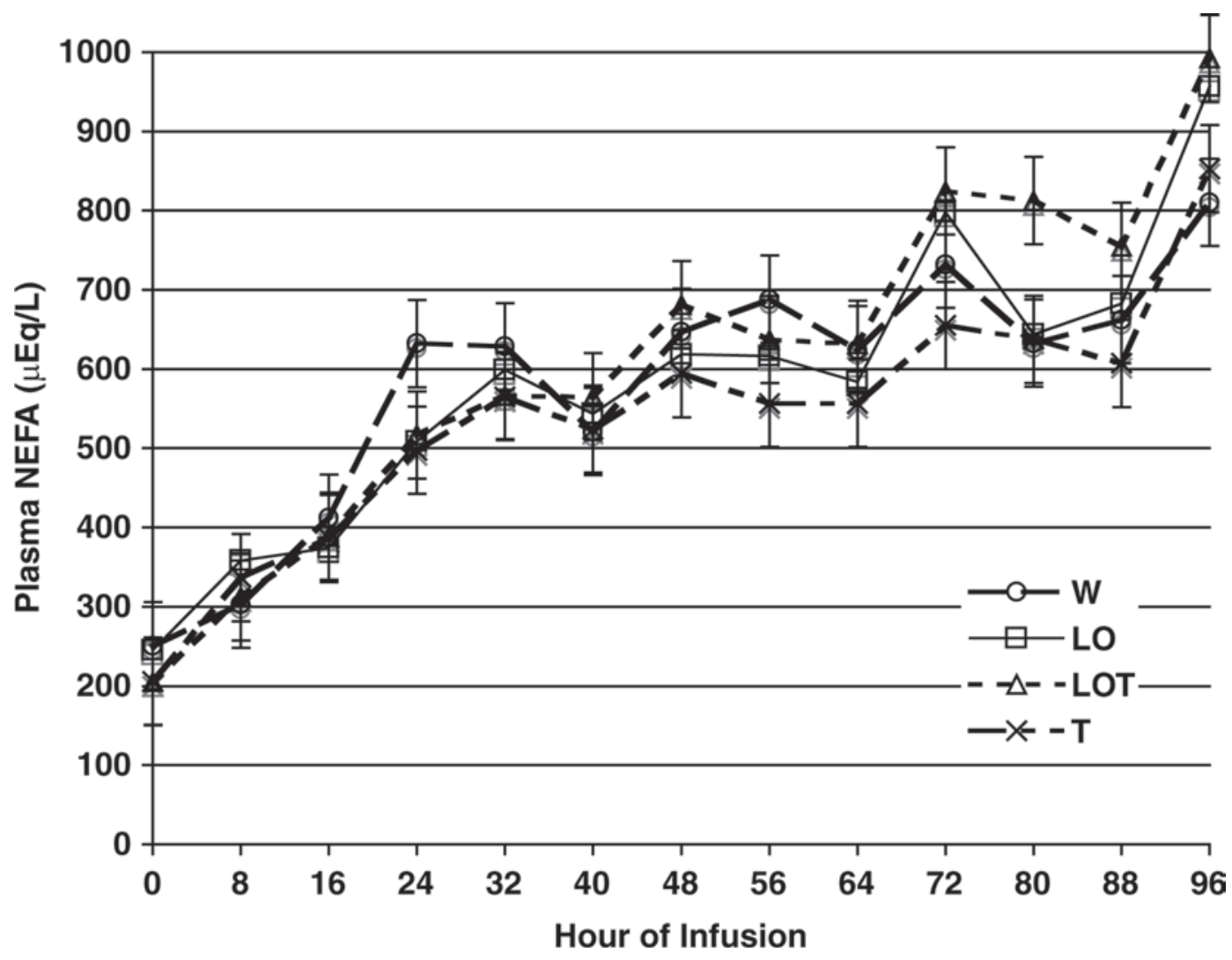

Figure 1. Effects of abomasal infusion of water (W), linseed oil (LO), linseed oil plus tallow (LOT), or tallow (T) at $0.56 \mathrm{~g} / \mathrm{kg}$ of BW per day on plasma NEFA concentration during a 4-d fast. Data represent LSM, and bars indicate SEM. 
Table 4. Effects of abomasal infusion of water (W), linseed oil (LO), linseed oil plus tallow (LOT), or tallow $(\mathrm{T})$ at $0.56 \mathrm{~g} / \mathrm{kg}$ of BW per day during a 4 -d fast on in vitro basal and stimulated release of NEFA and glycerol from subcutaneous adipose tissue explants ${ }^{1}$

\begin{tabular}{|c|c|c|c|c|c|}
\hline \multirow[b]{2}{*}{ Variable } & \multicolumn{4}{|c|}{ Infusion } & \multirow[b]{2}{*}{$\mathrm{SE}$} \\
\hline & W & $\mathrm{LO}$ & LOT & $\mathrm{T}$ & \\
\hline \multicolumn{6}{|l|}{ NEFA release } \\
\hline Basal & 2,691 & 2,929 & 2,736 & 2,593 & 268 \\
\hline Stimulated & 10,178 & 11,437 & 9,864 & 10,345 & 998 \\
\hline \multicolumn{6}{|c|}{ Glycerol release } \\
\hline Basal & 590 & 681 & 620 & 663 & 101 \\
\hline Stimulated $^{2}$ & 3,293 & 4,294 & 3,809 & 4,231 & 308 \\
\hline
\end{tabular}

${ }^{1}$ Results are expressed as nmol released $\times \mathrm{g}^{-1}$ tissue $\times 2 \mathrm{~h}^{-1}$.

${ }^{2}$ Significant contrast: Lipid (W vs. LO + LOT $+\mathrm{T} ; P=0.02$ ).

phospholipid, and cholesterol esters) tended to be higher in cows treated with LO than T $(P<0.08$; Figure 2 ). This could reflect differential absorption dynamics of fat sources, which were administered as abomasal boluses every $4 \mathrm{~h}$. Alternatively, LO may have changed metabolism and concentration of blood lipid fractions that contain fatty acids (e.g., TG, phospholipids, and cholesterol esters).

\section{In Vitro Adipose Tissue Lipolysis}

Lipolytic rates were measured in vitro, using adipose tissue explants collected at the end of each experimental period. Abomasal infusion of lipid increased isoproterenol-stimulated glycerol release $(P<0.02$; Table 4$)$, but had no effect on basal glycerol release (incubations without isoproterenol). This increased in vitro isoproterenol-stimulated lipolysis for cows receiving lipid was not accompanied by increased NEFA release in vitro

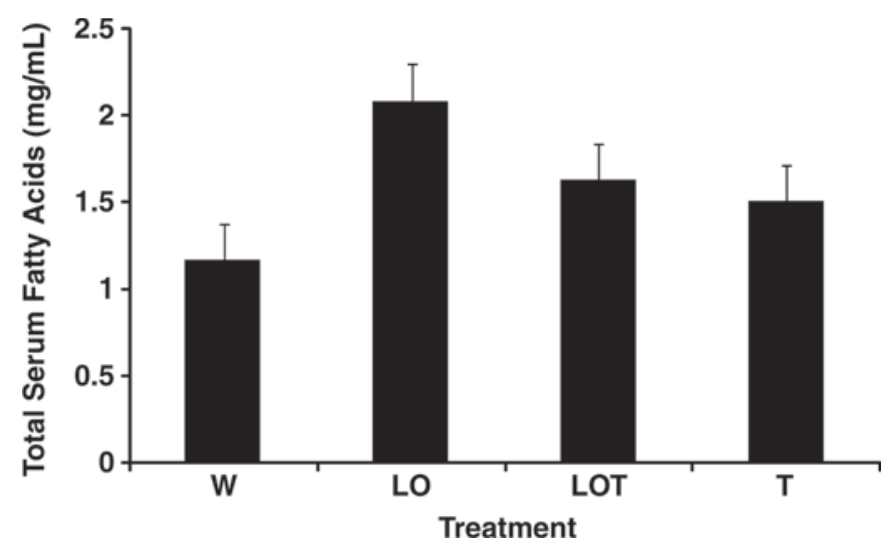

Figure 2. Effects of abomasal infusion of water (W), linseed oil (LO), linseed oil plus tallow (LOT), or tallow (T) at $0.56 \mathrm{~g} / \mathrm{kg}$ of BW per day on serum total fatty acids following a 4-d fast. Results are expressed as mg of total esterified plus NEFA $/ \mathrm{mL}$ of serum. Data represent LSM, and bars indicate pooled SEM. Contrasts: linear (LO vs. T; $P=0.08$ ) and nonlinear (LOT vs. LO $+\mathrm{T} ; P=0.06$ ) effects of LO.
(Table 4) or by changes in plasma NEFA concentrations (Figure 1). Adipocytes have limited ability to phosphorylate glycerol; therefore, glycerol is released during lipolysis, whereas NEFA can be re-esterified. As a result, glycerol release is considered a measure of total lipolysis and NEFA release a measure of net lipolysis (i.e., total lipolysis minus re-esterification). The lack of in vivo effect on plasma NEFA is in agreement with in vitro data, because only maximal lipolytic potential was changed by fat supplementation in this experiment. Similarly, duodenal rapeseed oil infusion increased in vitro and in vivo measures of basal and isoproterenolstimulated lipolysis in mid lactation dairy cows but not in early lactation (Gagliostro and Chilliard, 1991), indicating an interaction between physiologic state and metabolic responses to supplemental lipid. Increased stimulated lipolysis by feeding lipid may result from increased sensitivity of adipocytes to $\beta$-adrenergic agents (Gagliostro and Chilliard, 1991). Additionally, dietary lipid supplementation may cause some degree of insulin resistance in lactating dairy cows (Chilliard and Ottou, 1995; Gaynor et al., 1996). Nonetheless, there was no evidence of fat-induced whole-body insulin resistance when nonlactating cows were infused abomasally with lipid (approximately $400 \mathrm{~g} / \mathrm{d}$; Pires et al., 2008). There was no effect of lipid source on rates of lipolysis in vitro (Table 4), which agrees with plasma NEFA concentrations (Figure 1). Mashek et al. (2005) found lower plasma NEFA concentrations when cows were infused i.v. with an emulsion derived from LO compared with T. They speculated the decrease in NEFA concentration was due to a decrease in adipose tissue lipolysis. This hypothesis is not supported by the current study.

\section{Liver TG Content}

There were no period effects on TG content of liver samples collected immediately before initiation of feed restriction and administration of treatments. Basal 


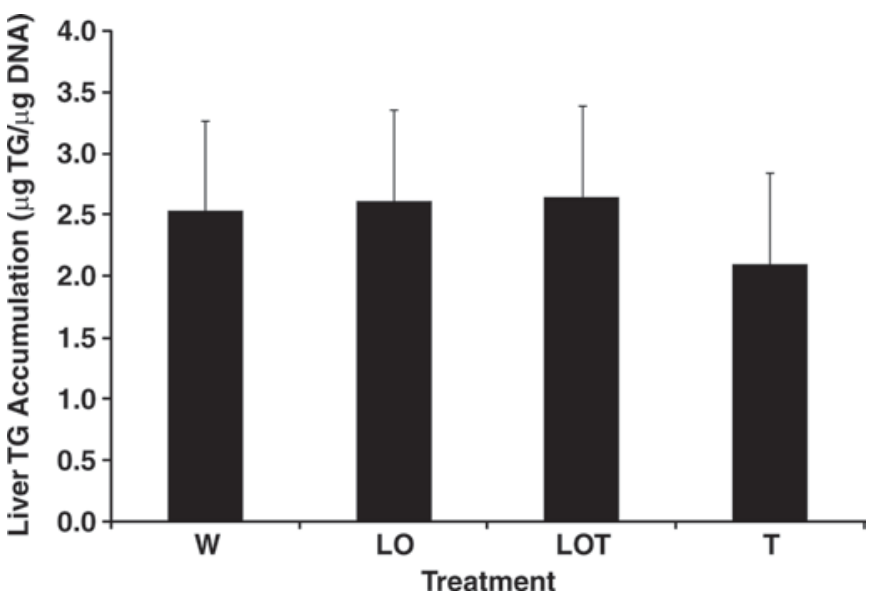

Figure 3. Effects of abomasal infusion of water (W), linseed oil (LO), linseed oil plus tallow (LOT), or tallow (T) at $0.56 \mathrm{~g} / \mathrm{kg}$ of BW per day on change in liver triglyceride (TG) concentration ( $\mu \mathrm{g}$ of TG/ $\mu \mathrm{g}$ of DNA) during a 4-d fast. Data represent LSM, and bars represent pooled SEM.

liver TG content was $0.74,0.84,0.68$, and $0.60 \pm 0.11$ $\mu \mathrm{g}$ of TG/ $\mu \mathrm{g}$ of DNA immediately before periods 1,2 , 3 , and 4 , respectively $(P=0.27)$. The recovery time between periods was sufficient to allow depletion of TG accumulated during experimental periods. Post-fast liver TG concentrations were $3.16,2.77,3.24$, and 3.46 $\pm 0.72 \mu \mathrm{g}$ of $\mathrm{TG} / \mu \mathrm{g}$ of DNA for $\mathrm{W}, \mathrm{T}, \mathrm{LO}$, and LOT, respectively $(P \geq 0.40$ for all treatment contrasts). There were no significant treatment effects on liver TG accumulation during the 4-d fast (Figure 3). These results contrast with previous research involving nonlactating cows, identical duration of feed restriction, and i.v. infusions of emulsions derived from $\mathrm{T}$, fish oil, or LO. Cows receiving emulsions derived from LO had the lowest plasma NEFA concentration and tended to have the lowest liver TG accumulation when compared with emulsions derived from T (Mashek et al., 2005). Nevertheless, because plasma NEFA and liver TG were decreased, it is unknown whether the reduction in liver TG was caused by direct effects on hepatocytes or indirect effects of LO on metabolism by peripheral tissues.

Based on in vitro incubations of hepatocytes with specific fatty acids, Mashek and Grummer (2003) concluded that ALA had the most beneficial effects on hepatic metabolism compared with other fatty acids, namely by eliciting numerically lower cellular TG concentration. In vivo, i.v. infusion of LO reduced liver TG accumulation concurrently with lower plasma NEFA, TG, and glucose concentrations (Mashek et al., 2005). In nonruminants, n-3 fatty acids decrease liver TG content by reducing de novo hepatic fatty acid synthesis and promoting oxidation of fatty acids (Morise et al., 2006). But, i.v. infusion of LO emulsion did not alter hepatic fatty acid oxidation in vitro. It was concluded that i.v. infusion of LO decreased liver TG either by acting directly upon hepatocytes to increase export of TG or oxidation of fatty acids; or indirectly to decrease adipose tissue lipolysis, resulting in lower blood NEFA uptake by liver. Nonetheless, in the current study, there were no effects of linseed oil on adipose tissue lipolysis in vitro, or treatment effects on plasma NEFA concentration. It is unknown how n-3 fatty acids may affect de novo lipogenesis, rates of fatty acid esterification, or very low density lipoprotein secretion by the ruminant liver.

Post-fast liver TG concentrations were lower in this study (2.8 and $3.2 \mu \mathrm{g}$ of TG/ $\mathrm{g}$ of DNA for T and LO, respectively) than when cows were infused i.v. with fatderived emulsions (12 and $8 \mu \mathrm{g}$ of TG/ $\mu \mathrm{g}$ of DNA for $\mathrm{T}$ and LO, respectively; Mashek et al., 2005). Emulsion particles were hydrolyzed less efficiently than chylomicrons by adipose tissue lipoprotein lipase and were cleared more slowly from blood (Hultin et al., 1995). Furthermore, both size and fatty acid composition of lipid particles affect catabolism of emulsion particles. For example, emulsion particles derived from fish oil were cleared faster from plasma than those consisting mainly of triolein in rats (Qi et al., 2003). Differences in metabolism of emulsion particles and chylomicrons may explain divergent results in plasma NEFA concentration and liver TG accumulation between the current and Mashek et al. (2005). Additionally, the modest accumulation of liver TG observed in this experiment may have prevented the detection of potential treatment effects.

\section{CONCLUSIONS}

Abomasal infusion of LO increased ALA in serum, but did not change adipose tissue lipolysis in vitro, which was consistent with no treatment effects on plasma NEFA concentration. There was a tendency for LO to increase total serum fatty acids (derived from NEFA, TG, phospholipid, and cholesterol esters), possibly indicating a greater absorption rate of this fat source, or differences in lipid metabolism. Linseed oil failed to decrease plasma NEFA concentration or reduce liver TG accumulation, which contrasts with a previous study involving i.v. infusion of emulsions (Mashek et al., 2005). It is unknown how metabolism of intestinally derived chylomicrons may differ from emulsion particles in ruminants and how these differences could account for the conflicting results of this experiment and that of Mashek et al. (2005). Additionally, the relatively modest accumulation of liver TG observed may have precluded potential beneficial effects of LO from being expressed. 


\section{REFERENCES}

AbuGhazaleh, A. A., D. J. Schingoethe, A. R. Hippen, and K. F. Kalscheur. 2003. Conjugated linoleic acid and vaccenic acid in rumen, plasma, and milk of cows fed fish oil and fats differing in saturation of 18 carbon fatty acids. J. Dairy Sci. 86:3648-3660.

Bremmer, D. R., L. D. Ruppert, J. H. Clark, and J. K. Drackley. 1998. Effect of chain length and unsaturation of fatty acid mixtures infused into the abomasum of lactating dairy cows. J. Dairy Sci. 81:176-188.

Cadorniga-Valino, C., R. R. Grummer, L. E. Armentano, S. S. Donkin, and S. J. Bertics. 1997. Effects of fatty acids and hormones on fatty acid metabolism and gluconeogenesis in bovine hepatocytes. J. Dairy Sci. 80:646-656.

Chelikani, P. K., J. A. Bell, and J. J. Kennelly. 2004. Effects of feeding or abomasal infusion of canola oil in Holstein cows. 1. Nutrient digestion and milk composition. J. Dairy Res. 71:279-287.

Chilliard, Y. 1993. Dietary fat and adipose tissue metabolism in ruminants, pigs and rodents: A review. J. Dairy Sci. 76:38973931.

Chilliard, Y., and J. F. Ottou. 1995. Duodenal infusion of oil in midlactation cows. 7. Interaction with niacin on responses to glucose, insulin, and beta-agonist challenges. J. Dairy Sci. $78: 2452-2463$

Doreau, M., and Y. Chilliard. 1997. Digestion and metabolism of dietary fat in farm animals. Br. J. Nutr. 78:S15-S35.

Emery, R. S., J. S. Liesman, and T. H. Herdt. 1992. Metabolism of long chain fatty acids by ruminant liver. J. Nutr. 122(Suppl.):832-837.

Gagliostro, G., and Y. Chilliard. 1991. Duodenal rapeseed oil infusion in early and midlactation cows. 4 . In vivo and in vitro adipose tissue lipolytic responses. J. Dairy Sci. 74:1830-1843.

Gaynor, P. J., R. A. Erdman, B. B. Teter, A. V. Capuco, and D. R. Waldo. 1996. Glucose and norepinephrine challenges during the abomasal infusion of cis or trans octadecenoates in Holstein cows. J. Dairy Sci. 79:1590-1595.

Gressley, T. F., S. M. Reynal, J. J. O. Colmenero, G. A. Broderick, and L. E. Armentano. 2006. Technical note: Development of a tool to insert abomasal infusion lines into dairy cows. J. Dairy Sci. 89:3965-3967.

Grummer, R. R. 1993. Etiology of lipid-related metabolic disorders in periparturient dairy cows. J. Dairy Sci. 76:3882-3896.

Hultin, M., C. Carneheim, K. Rosenqvist, and T. Olivecrona. 1995. Intravenous lipid emulsions: Removal mechanisms as compared to chylomicrons. J. Lipid Res. 36:2174-2184.

Ikeda, I., J.-Y. Cha, T. Yanagita, N. Nakatani, K. Oogami, K. Imaizumi, and K. Yazawa. 1998. Effects of dietary alpha-linolenic, eicosapentaenoic and docosahexaenoic acids on hepatic lipogenesis and beta-oxidation in rats. Biosci. Biotechnol. Biochem. 62:675680 .

Johnson, M. M., and J. P. Peters. 1993. Technical note: An improved method to quantify nonesterified fatty acids in bovine plasma. J. Anim Sci. 71:753-756.
Kleppe, B. B., R. J. Aiello, R. R. Grummer, and L. E. Armentano. 1988. Triglyceride accumulation and very low density lipoprotein secretion by rat and goat hepatocytes in vitro. J. Dairy Sci. 71:1813-1822.

Lessard, M., N. Gagnon, and H. V. Petit. 2003. Immune response of postpartum dairy cows fed flaxseed. J. Dairy Sci. 86:2647-2657.

Lomax, M. A., I. A. Donaldson, and C. I. Pogson. 1983. The control of fatty acid metabolism in liver cells from fed and starved sheep. Biochem. J. 214:553-560.

Mashek, D. G., S. J. Bertics, and R. R. Grummer. 2005. Effects of intravenous triacylglycerol emulsions on hepatic metabolism and blood metabolites in fasted dairy cows. J. Dairy Sci. 88:100109.

Mashek, D. G., and R. R. Grummer. 2003. Effects of long chain fatty acids on lipid and glucose metabolism in monolaver cultures of bovine hepatocytes. J. Dairy Sci. 86:2390-2396.

McGowan, M. W., J. D. Artiss, D. R. Strandbergh, and B. Zak. 1983. A peroxidase-coupled method for the colorimetric determination of serum triglycerides. Clin. Chem. 29:538-542.

McNamara, J. P., and J. K. Hillers. 1986. Adaptations in lipid metabolism of bovine adipose tissue in lactogenesis and lactation. J. Lipid Res. 27:150-157.

Morise, A., J. Mourot, C. Boue, N. Combe, G. Amsler, D. Gripois, A. Quignard-Boulange, L. Yvan-Charvet, E. Fenart, P. Weill, and D. Hermier. 2006. Gender-related response of lipid metabolism to dietary fatty acids in the hamster. Br. J. Nutr. 95:709-720.

NRC. 2001. Nutrient Requirements of Dairy Cattle. 7th rev. ed. Natl. Acad. Sci., Washington, DC.

Pires, J. A. A., J. B. Pescara, A. E. Brickner, N. Silva del Rio, A. P. Cunha, and R. R. Grummer. 2008. Effects of abomasal infusion of linseed oil on responses to glucose and insulin in Holstein cows. J. Dairy Sci. 91:1378-1390.

Qi, K., M. Al-Haideri, T. Seu, Y. A. Carpentier, and R. J. Deckelbaum. 2003. Effects of particle size on blood clearance and tissue uptake of lipid emulsions with different triglyceride compositions. J. Parenter. Enter. Nutr. 27:58-64.

Strang, B. D., S. J. Bertics, R. R. Grummer, and L. E. Armentano. 1998. Effect of long-chain fatty acids on triglyceride accumulation, gluconeogenesis, and ureagenesis in bovine hepatocytes. J. Dairy Sci. 81:728-739.

Sukhija, P. S., and D. L. Palmquist. 1998. Rapid method for determination of total fatty acid content and composition of feedstuff and feces. J. Agric. Food Chem. 36:1202-1206.

Vazquez-Anon, M. 1996. Adipose tissue metabolism in periparturient cows: Relationship to the development of fatty liver. $\mathrm{PhD}$ Thesis. University of Wisconsin-Madison.

Vazquez-Anon, M. S., S. J. Bertics, M. Luck, and R. R. Grummer. 1994. Peripartum liver triglyceride and plasma metabolites. J. Dairy Sci. 77:1521-1528.

Veenhuizen, J. J., J. K. Drackley, M. J. Richard, T. P. Sanderson, L. D. Miller, and J. W. Young. 1991. Metabolic changes in blood and liver during development and early treatment of experimental fatty liver and ketosis in cows. J. Dairy Sci. 74:4238-4253. 